\title{
PENILAIAN PENGETAHUAN TERTULIS DALAM KURIKULUM 2013
}

\begin{tabular}{lll}
\hline Received: 08-05-2020 & Revised: 22-06-2020 & Accepted: 30-07-2020 \\
\hline
\end{tabular}

Nurul Waizah ${ }^{1}$, Herwani ${ }^{2}$

Institut Agama Islam Sultan Muhammad Syafiuddin Sambas ${ }^{1}$

Sekolah Tinggi Ilmu Tarbiyah (STIT) Syarif Abdurrahman Singkawang, Indonesia 2

nurulwaizah76@gmail.com, herwani119033@gmail.com

\section{Keywords:}

Assessment,

Written

Knowledge,

Curriculum 2013

\section{ABSTRAK}

Kata Kunci:

Penilaian,

Pengetahuan

Tertulis,

Kurikulum 13

\begin{abstract}
Penilaian ini diperlukan untuk mengukur apakah siswa sudah berhasil mencapai kompetensi atau belum maka diperlukan informasi hasil belajar. Informasi hasil belajar itu diperoleh dari tagihan-tagihan yang harus dipenuhi oleh siswa. Setiap jenis tagihan memerlukan seperangkat alat ukur atau alat penilaian.Di sini perlu peran guru untuk mampu membuat alat ukur dan mengumpulkan informasi hasil belajar dengan tepat Alat ukur atau alat penilaian yang dapat menghasilkan hasil pengukuran valid dan reliabel. Penilaian kompetensi pengetahuan atau kognitif adalah penilaian yang dilakukan guru untuk mengukur tingkat pencapaian atau penguasaan peserta didik dalam aspek pengetahuan yang meliputi ingatan atau hafalan, pemahaman, penerapan atau aplikasi, analisis, sintesis dan evaluasi. Kurikulum 2013 adalah sebagai landasan filosofi yang mengembangkan seluruh potensi peserta didik menjadi manusia yang berkualitas.
\end{abstract}

\section{ABSTRACT}

This assessment is needed to measure whether students have succeeded in achieving competence or not; information on learning outcomes is needed. Information on learning outcomes is obtained from bills that students must meet. Each type of bill requires a set of measuring tools or assessment tools. Here, the teacher's role is needed to make measuring tools and gather information on learning outcomes appropriately. They measure tools or assessment tools that can produce valid and reliable measurement results. Assessment of knowledge or cognitive competence is an assessment carried out by teachers to measure students' achievement or mastery in aspects of knowledge, including memory or memorization, understanding, application or application, analysis, synthesis, and evaluation. The 2013 curriculum is a philosophical foundation that develops all the potential of students to become quality human beings. 


\section{PENDAHULUAN}

Tugas pokok seorang guru diantaranya adalah menilai pemcapaian hasil belajar peserta didik. Profesi guru tentu tidak terlepas dari kegiatan pengukuran dan penilaian (mengukur,menakar, dan menimbang)1. Sebagai konsekuensi logis dari pelaksanaan perencanaan pembelajaran yang telah disusun setiap awal semester. Penilaian ini dimaksudkan untuk mengambil keputusan tentang keberhasilan siswa dalam mencapai kompetensi yang telah ditetapkan².

Kompetensi yang harus dikuasai peserta didik tidaklah sama untuk setiap mata pelajaran, tetapi tergantung pada karakteristik mata pelajaran tersebut. Secara garis besar pencapaian suatu kompetensi mata pelajaran mencakup ranah kognitif, afektif dan psikomoter. Kita mengenal banyak jenis tes yang dilaksanakan di sekolah ,misalnya tes seleksi, tes penempatan, pre-tes-post tes, tes formatif, tes diagnostik, tes sumatif dan tes unjuk kerja ${ }^{3}$.

Tes tersebut mempinyai fungsi dan tujuan tertentu. Tes seleksi untuk menyelekssi atau memilih calon yang dapat diterima untuk mengikuti suatu program. Tes penempatan untuk mengelompokkan peserta didik dalam satu kelompok yang relatif homogen dan kemampuan dan keterampilannya. Pre-tes dimaksudkan untuk mengetahui sejauh mana peserta didik telah memahami

1 Jeprianto Jeprianto, Ubabuddin Ubabuddin, and Herwani Herwani, 'Penilaian Pengetahuan Penugasan Dalam Pembelajaran Di Sekolah', Munaddhomah: Jurnal Manajemen Pendidikan Islam 2, no. 1 (23 June 2021): 16-20, https://pasca.jurnalikhac.ac.id/index.php/munaddhomah/article/view/55; Saiful Asyari, 'Supervisi Kepala Madrasah Berbasis Penilaian Kinerja Sebagai Upaya Peningkatan Profesionalitas Guru', JIEMAN: Journal of Islamic Educational Management 1, no. 2 (24 June 2020): 149-63, https:// doi.org/10.35719/jieman.v1i2.14.

${ }^{2}$ Muhamad Faisal Ashaari et al., 'An Assessment of Teaching and Learning Methodology in Islamic Studies', Procedia - Social and Behavioral Sciences, Universiti Kebangsaan Malaysia Teaching and Learning Congress 2011, Volume I, December 17 - 20 2011, Pulau Pinang MALAYSIA, 59 (17 October 2012): 618-26, https:/ / doi.org/10.1016/j.sbspro.2012.09.322; Joanna Drugan, Quality In Professional Translation: Assessment and Improvement (A\&amp;C Black, 2013).

${ }^{3}$ Matthew T. Brodhead et al., 'An Evaluation of a Brief Multiple-Stimulus Without Replacement Preference Assessment Conducted in an Electronic Pictorial Format', Journal of Behavioral Education 25, no. 4 (1 December 2016): 417-30, https://doi.org/10.1007/s10864-0169254-3; Atikah Atikah, Nasir Widha Setyanto, and Ceria Farela Mada Tantrika, 'Perancangan Penilaian Kinerja Guru Berdasarkan Standar Kualifikasi Akademik Kompetensi Guru Dan Kompetensi Gomes Sebagai Acuan Pemberian Insentif (Studi Kasus Sma Brawijaya Smart School, Malang)', Jurnal Rekayasa Dan Manajemen Sistem Industri 1, no. 3 (2013): p464-475, http://jrmsi.studentjournal.ub.ac.id/index.php/jrmsi/article/view/53. 
materi pelajaran yang akan disampaikan, sedangkan post-tes dapat digunakan untuk mengetahui sejauh mana siswa dapat mencapai tujuan program setelah mereka mengikuti program tersebut. Dengan demikian pre-test dan post tes dapat digunakan untuk menilai efektivitas proses pembelajaran yang yang telah dilaksanakan. Tes formatif untuk mengetahui sejauh mana peserta didik dapat menguasai tujuan pembelajaran yang baru saja disampaikan ${ }^{4}$.

Jika masih banyak siswa yang belum dapat mencapai tujuan maka program pembelajaran tersebut harus diulang5. Dengan demikian tes formatif dapat digunakan untuk memperbaiki proses pembelajaran yang dilakukan. Tes diagnostik untuk mengetahui kesulitan yang dialami siswa dalam memahami materi pelajaran. Tes ini sebagai langkah awal untuk menentukan dan memperbaiki atau menghilangkan penyebab kesulitan siswa dalam memahami suatu pelajaran' ${ }^{6}$ Tes sumatif dimaksudkan untuk menilai keberhasilan siswa setelah mengikuti seluruh rangkaian proses pembelajaran, dengan demikian tes sumatif digunakan untuk menilai hasil belajar siswa. Sedangkan tes unjuk kerja digunakan untuk menilai performance siswa dalam menghayati atau menghasilkan suatu karya atau hasil belajar.7 Dari beberapa tes ini menggunakan bentuk penilaian pengetahuan tertulis Berikut ini peneliti akan menjabarkan konsep serta hal-hal yang berhubungan dengan penilaian pengetahuan tertulis.

${ }^{4}$ Bahrissalim Bahrissalim and Fauzan Fauzan, 'Evaluasi Kurikulum Pelatihan Dalam Meningkatkan Kompetensi Pedagogik Guru Pai Di Balai Diklat Keagamaan Jakarta', Edukasia: Jurnal Penelitian Pendidikan Islam 13, no. 1 (25 July 2018): 25-52, https://doi.org/10.21043/edukasia.v13i1.2779; Zainal Arifin, 'Evaluasi Pembelajaran', Bandung: Remaja Rosdakarya 77 (2009), http://dualmode.kemenag.go.id/file/dokumen/34EvaluasiPembelajaran.pdf.

${ }^{5}$ Hayward P. Andres, 'Active Teaching to Manage Course Difficulty and Learning Motivation', Journal of Further and Higher Education 43, no. 2 (7 February 2019): 220-35, https://doi.org/10.1080/0309877X.2017.1357073; Ah Zakki Fuad, 'Rekonstruksi Tujuan Pendidikan Islam Berbasis Taksonomi Transenden', ISLAMICA: Jurnal Studi Keislaman 9, no. 2 (15 March 2016): 424-46, https:// doi.org/10.15642/islamica.2015.9.2.424-446.

${ }^{6}$ Munaya Ulil Ilmi et al., 'The Basic Concepts of Evaluation and Its Implementation in IRE Lessons in The Pandemic Era', Tafkir: Interdisciplinary Journal of Islamic Education 2, no. 2 (30 July 2021): 175-90, https://doi.org/10.31538/tijie.v2i2.50; Israel Dunmade, 'Lifecycle Assessment Education in Nigeria: An Exploratory Evaluation of the Trend', Procedia Manufacturing 35 (1 January 2019): 447-52, https:/ / doi.org/10.1016/j.promfg.2019.05.065.

7 Adi Suryanto, 'Evaluasi Pembelajaran Di SD', vol. 1 (Jakarta: Universitas Terbuka, 2014), 1-49, http://repository.ut.ac.id/4070/. 


\section{Nurul Waizah, Herwani}

\section{PEMBAHASAN}

\section{Definisi Penilaian Pengetahuan Tertulis}

Penilaian kompetensi pengetahuan atau kognitif adalah penilaian yang dilakukan guru untuk mengukur tingkat pencapaian atau penguasaan peserta ddik dalam aspek pengetahuan yang meliputi ingatan atau hafalan, pemahaman, penerapan,atau aplikasi analisis, sintesis dan evaluasi. ${ }^{8}$ Dalam kurikulum 2013 kompetensi pengetahuan disebut dengan kd kompetensi inti 3 (KI 3) sebagai refleksi konsep-konsep keilmuan yang harus dikuasai peserta didik dalam proses belajar mengajar. Ranah kompetensi pengetahuan (kognitif) ada enam jenjang proses berpikir yaitu:

Pengetahuan Hafalan (Knowledge)

Pengetahuan (knowledge) merupakan kemampuan seseorang untuk mengingat kembali (recall) atau mengenal kembali tentang nama, istilah, ide, gejala, nama-nama dan sebagainya tanpa mengharapkan kemampuan untuk menggunakannya. Pengetahuan atau ingatan ini adalah merupakan proses berpikir yang paling rendah, kemampuan mengetahui juga dapat diartikan kemampuan mengenal fakta, konsep, prinsip dan skill. ${ }^{9}$

Kegiatan pembelajaran dapat difokuskan melalui mengemukakan arti, membuat daftar, medeskripsikan sesuatu, menderiakan sesuatu yang terjadi, menguraikan sesuatu yang terjadi, menentukan lokasi tempat dan memberi nama.

Pemahaman (Comprehension)

Pemahaman (comprehension) adalah kemampuan seseorang untuk mengerti atau memahami sesuatu setelah seauatu itu diketahui atau diingat, dengan demikian memahami adalah mengetahui tentang sesuatu dan dapat melihatnya dari berbagai aspek. ${ }^{10}$

Peserta didik dikatakan memahami seuatu apabila dapat memberikan penjelasan atau memberikan uraian yang rinci dengan kata-

8 Loeloek Endah Poerwati; Sofan Amri, Panduan Memahami Kurikulum 2013: Sebuah Inovasi Struktur Kurikulum Penunjang Masa Depan (Jakarta: Prestasi Pustaka Pub, 2013).

${ }_{9}^{9}$ Amri, 64.

10 Oemar Hamalik, Manajemen pengembangan kurikulum (Sekolah Pascasarjana Universitas Pendidikan Indonesia dengan PT Remaja Rosdakarya, 2006), 132. 
katanya sendiri. Pemahaman merupakan jenjang kemampuan berpikir setingkat lebih tinggi dari hafalan atau ingatan, kemempuan memahami juga dapat diartikan kemempuan mengerti tentang hubungan antara faktor, antar prinsip, antar data, hubungan sebab akibat, dan penarikan kesimpulan. ${ }^{11}$

Penerapan (Aplication)

Penerapan atau aplikasi adalah kesanggupan seseotang untuk menerapkan atau menggnakan ide-ide umum, tata cara ataupun metodemetode, prinsip-prinsip, rumus-rumus teori-teori dan sebagainya dalam situasi yang baru dan kongkret. ${ }^{12}$

Analisis (Analyisis)

Analisis (analysis) adalah kemmpuan seseoramg untuk merinci atau menguraikan suatu bahan atau keadaan menurut bagian-bagian ynag lebih kecil dan mampu memahami hubungan di antara bagian-bagian atau faktor-faktor yang satu dengan faktor-faktor lainnya. Analisis merupakan proses berpikir yang setingkat lebih tinggi dari penerapan atau aplikasi. Kemampuan analisis juga dapat diartikan menemukan bagian-bagian dari sutau masalah dan penyelesaian atau gagasan serta menunjukkan hubungan antar bagian itu. ${ }^{13}$

Sintesis (Syinthesiss)

Sintesis adalah kemampuan berpikir yang merupakan kebalikan dari proses berpikir analisis. Sintesis merupakan suatu proses yang memadukan bagian-bagian atau unsur-unsur secara logis, sehingga menjelma menjadi suatu pola yang berstruktur atau berbentuk pila baru.

11 Latifatul Mida Muzamirah, Kupas Tuntas Kurikulum 2013 : Kelebihan Dan Kekurangan Kurikulum 2013 | Perpustakaan Universitas Negeri Jakarta (Yogjakarta: Kata Pena, 2013), //lib.unj.ac.id\%2Fbuku\%2Findex.php\%3Fp\%3Dshow_detail\%26id\%3D34149\%26keywords\%3 D.

12 A. Ferry; Indratno, Forum Mangunwijaya VII : Menyambut Kurikulum 2013 (Jakarta: PT Kompas Media Nusantara, 2013), //library.alizhar.sch.id/slims8_akasia/index.php?p=show_detail\&id=2321.

13 E. Mulyasa, Pengembangan Dan Implementasi Kurikulum 2013, Cetakan pertama (Bandung: PT Remaja Rosdakarya, 2013), 66. 


\section{Nurul Waizah, Herwani}

Berpikir sintesis merupakan proses berpikir yang setingkat lebih tinggi dari berpikir analisis. ${ }^{14}$

Penerapannya dalam pembelajaran ditunjukkan melalui menyelesaikan penyelesaian atau solusi masalah, memprediksi, merancang model produk tertentu, membuat desain, dan menciptakan produk tertentu.

Evaluasi (Evaluation)

Evaluasi atau evaluation adalah kemampuan seseorang untuk membuat pertimbangan terhadap suatu situasi, nilai atau ide. Misalnya jika seseorang dihadapkan pada beberapa pilihan, maka ia akan mampu memilih satu pilihan terbaik, sesuai dengan patokan-patokan atau kriterian tertentu. Kemampuan melakukan evaluasi juga dapat diartikan mempertimbangkan dan menilai bena salah, baik, buruk, bermanfaat dan tidak bermanfaat. ${ }^{15}$

Dalam kegiatan pembelajaran ditunjukkan dengan lemampuan mempertahankan pendapat, beradu pendapat, nenilih soludi terbaik, menyusun kriteria penilaian, menyarankan perubahan, menulis laporanm, menyarankan strategi baru dan membahas suatu kasus.

Ada tiga istilah yang berkaitan dengan penilaian yakni, evaluasi, pengukuran (measurement) dan assesment. Evaluasi menurut Kourilkski adalah the act of determining the degree to which and individual or group possesses the xertain atribute ( tindakan tentang penetapan derajat penguasaan atribut tertentu oleh indivisu atau (kelompok)16. Evaluasi umumnya berpusat kepada peserta didik, yang dinaksudkan untuk mengamati hasil belajar peserta didik dan berupaya menentukan bagaimana menciptakan kesempatan belajar. Evaluasi juga dimaksudkan

14 Kunandar, Penilaian Autentik (Penilaian Hasil Belajar Peserta Didik Berdasarkan Kurikulum 2013), Suatu Pendekatan Praktis I Perpustakaan FIS (Jakarta: Raja Grafindo Persada, 2013), //library.fis.uny.ac.id\%2Fopac\%2Findex.php\%3Fp\%3Dshow_detail\%26id\%3D6258.

${ }^{15}$ Hamalik, Manajemen pengembangan kurikulum, 87.

${ }^{16}$ Choirul Mahfud, 'Evaluation of Islamic Education Curriculum Policy in Indonesia', Premiere Educandum: Jurnal Pendidikan Dasar Dan Pembelajaran 9, no. 1 (2019): 34-43; Gert-Jan M. Veerman, Herman G. van de Werfhorst, and Jaap Dronkers, 'Ethnic Composition of the Class and Educational Performance in Primary Education in The Netherlands', Educational Research and Evaluation 19, no. 5 (1 July 2013): 370-401, https:/ / doi.org/10.1080/13803611.2013.788851.

Vol.2, No.2, July 2021

Tafkir: Interdisciplinary Journal of Islamic Education 
untuk mengamati peranan guru, strategi pengajaran khusus, materi kurikulum dan prinsip-prinsip belajar untuk diterapkan pada pengajaran. Fokusnya adalah bagaimana dan mengapa peserta didik bertindak dalam pengajaran serta apa yang mereka lakukan. Tujuan evaluasi untuk mempernaiki pengajaran dan penguasaan tujuan tertentu dalam kelas.

Menurut Percival, evaluation ... as a series of activities that are dsigned to measure the effectiveness of a teaching/learning syistem as awhole ( evaluasi adalah serangkaian kegiatan yang dirancang untuk mengukur keefektifan sistem belajar/mengajar sebagai suatu keseluruhan) ${ }^{17}$.

Assesment adalah serangkaian kegiatan yang dirancang unutk mengukur proses belajar (achiavement) peserta didik sebagai hasil dari suatu program instruksional, rumusan ini menunjukkan bahwa hasil assesment terhadap peserta didik dapat digunakan sebagai bukti yang patut dipertimbangakan dalam rangka evaluasi pengajaran.

Karakteristik prossedur assesment peserta didik harus valid, reliable, practicable, fair, dan berguna. Valid adalah apabila secara aktual menguji apa yang ingin diuji artinya mengukur tingkah laku yang telah ditentukan / dirumuskan pada tujuan. Reliable adalah mengukur konsistensi dengan pertanyaan, pengetesan menghasilkan hasil yang sama ynag dicapai oleh populasi siswa kendati dalam kondisi yang berbeda atau sebanding. Prosedur asessment yang praktis secara realistis murah biayanya sesuai dengan waktu dan mudah melaksanakannya. Asessment yang fairness dan usefulness karena akurat yang merefleksikan tingkah laku yang diharapkan sebagaimana ditetapkan dalam tujuan pelajaran. Kegunaannya karena hasilnya memberikan umpan balik tentang kemampuan peserta didik (kekuatan dan kekurangan) pengukuran atau measurement berkenaan dengan pengumpulan data deskriftif tentang produk peserta didik dan atau/tingkah laku peserta didik dan hubungannya dengan standar prestasi atau norma. Evaluasi menunjuk pada teknik-teknik pengukuran, baik

17 N. J. PERCIVAL, P. J. SYKES, and T. CHANDRAPRAKASAM, 'A Method of Assessment of Pollicisation', Journal of Hand Surgery 16, no. 2 (1 April 1991): 141-43, https://doi.org/10.1016/0266-7681(91)90163-I. 


\section{Nurul Waizah, Herwani}

data rangka asessment peserta didik maupun terhadap proses instruksional menyeluruh yang meliputi urutan instruksional, (perencanaaan, penyampaian, tindak lanjut) dan perubahan tingkah laku peserta didik yang dapat diamati (kognitif, psikomotorik dan afektif). Aplikasi teknik pengukuran difokuskan pada dua jenis, yakni pengukuran acuan norma dan pengukuran acuan kriteria. ${ }^{18}$ Sesia dengan Peraturan Pemerintah No. 19 Tahun 2006 tentang SNP: Penilaian adalah proses pengumpulan informasi untuk mengukur pencapaian hasil belajar peserta didik. ${ }^{19}$

Pengetahuan tertulis biasa juga dibuat dalam bentuk tes. Kata tes secara harfiah berasal dari Bahasa Perancis kunu "testum" artinya piring untuk menyisihkan logam-logam mulia. Tes adalah serangkaian pertanyaan atau latihan atau alat lain yang digunakan untuk mengukur keterampilan, pengetahuan, kecerdasan, kemampuan atau alat yang dimiliki oleh seseorang atau kelompok.

Dengan kata lain tes merupakan alat ukur yang berbentuk pertanyaan atau latihan digunakan untuk mengukur kemampuan yang ada pada seseorang atau sekelompok orang. Sebagai alat ukur dalam bentuk pertanyaan maka tes harus dapat memberikan informasi mengenai pengetahuan dan kemampuan objek yang diukur. Sedangkan sebagai alat ukur berupa latihan maka tes harus dapat mengungkap keterampilan dan bakat seseorang atau seekompok orang.

Jadi tes adalah suatu cara atau alat untuk mengadakan penilaian yang berbentuk suatu tugas atau serangkaian tugas yang harus dikerjakan oleh peserta didik atau sekelompok peserta didik sehingga menghasilkan nilai tentang tingkah laku atau prestasi siswa tersebut yang menunjukkan tingkat pencapaian tujuan instruksional pembelajaran atau tingkat penguasaan terhadap seperangkat materi yang telah diberikan dalam proses pembelajaran dan dapat juga menunjukkan kedudukan siswa yang bersangkutan dalam kelompoknya.

18 Oemar Hamalik, Proses belajar mengajar (Bumi Aksara, 2004).
19 Peraturan Pemerintah No. 19 Tahun 2006 tentang SNP. 


\section{Dasar Filosofis}

Kurikulum merupakan unsur penting dalam setiap bentuk dan model pendidikan. Tanpa adanya kurikulum, sulit bagi perencana pendidikan dalam mencapai tujuan pendidikan yang diselenggarakannya. Mengingat pentingnya kurikulum maka kurikulum perlu dipahami dengan baik dan semua pelaksana pendidikan. ${ }^{20}$

Kata kurikulum berasal dari istilah Yunani Kuno yaitu carii yang artinya pelajari dan curer artinya tempat berpacu atau tempat berlomba Sedangkan kurikulum mempunyai arti "jarak" yang harus ditempuh oleh pelari dari start sampai finish ountuk memperoleh medali. ${ }^{21}$ Kurikulum dalam dunia pendidikan memilki pengertian sebagai sejumlah mata pelajaran yang harus ditempuh sampai akhir hingga mendapatkan ijazah.

Kurikulum adalah seperangkat rencana dan pengaturan mengenai tujuan, isi dan bahan pelajaran serta cara yang digunakan sebagai pedoman penyelenggaraan kegiatan pembelajaran untuk mencapai tujuan pendidikan tertentu. $^{22}$ Kurikulum 2013 sebagi implementasi dari Peraturan Menteri Pendidikan dan Kebudayaan Republik Indonesia Nomor 65 Tahun 2013 Tentang Standar Proses Pendidikan Dasar dan Menengah, Kurikulum 2013 merupakan Kurikulum lanjutan Pengembangan Kurikulum Berbasis Kompetensi. Dan melalui Peraturan Kementerian pendidikan dan kebudayaan pada tahun 2013 mengimplementasi kurikulum baru sebagai penyempurnaan kurikulum sebelumnya (KTSP 2006) yang diberi nama Kurikulum 2013.

Dalam kurikulum 2013 dikembangkan landasan filosofis sebagai dasar pengembangan seluruh potensi peserta didik menjadi manusia berkualitas sesuai tujuan pendidikan nasional sebagai landasan filosofis kurikulum menentukan kualitas peserta didik yang akan dicapai kurikulum, sumber dan isi dari kurikulum, proses pembelajaran, posisi peserta didik, penilaian hasil

20 Suyanto, Refleksi Dan Reformasi Pendidikan Di Indonesia Memasuki Milenium III (Yogjakarta: Adicita Karya Nusa, 2000).

${ }^{21}$ Anin Nurhidayati, Kurikulum Inovasi. Yogyakarta: Teras, 2012: 2

22 Undang-Undang Republik Indonesia No.20 Tahun 2002 Tentang Sistem Pendidikan Nasional Pasal I 


\section{Nurul Waizah, Herwani}

belajar, hubungan peserta didik dengan masyarakat dan lingkungan alam sekitarnya. ${ }^{23}$

Kurikulum 2013 dikembangkan dengan landasan filosofis yang merupakan dasar pengembangan seluruh potensi peserta didik menjadi manusia Indonesia yang berkualitas. Menurut Kusnandar kurikulum 2013 dikembangkan berdasarkan filodofi sebagai berikut:24 1) Pendidikan berakar pada budaya bangsa untuk membangun kehidupan bangsa masa kini dan masa mendatang. Budaya bangsa beragam diarahkan untuk membangun kehidupan masa kini sebagai dasar untuk kehidupan bangsa di masa depan akan lebih baik. 2) Peserta didik adalah pewaris budaya nbangsa yang kreatif. Adanya berbagai prestasi bangsa di berbagai bidang pada masa lampau adalah gambaran bahwa peserta didk harus terus belajar mengembangkan potensi diri, meningkatkan kemampuan berpikir rasional dan juga menimbulakna rasa bangga terhadap budaya bangsa. 3) Pendidikan bertujuan untuk mengembangkan kecerdasan intelektual melalui pendidikan disiplin ilmu. Filosofi ini menentukan bahwa isi kurikulum adalah disiplin ilmu dan pembelajaran adalah pembelajaran disiplin ilmu (essentialism). 4) Pendidikan untuk membangun kehidupan masa kini dan dan masa depan yang lebih baik dari masa lalu dengan berbagai kemampuan berkomunikasi, sikap sosial, kepedulian, dan berpartisipasi untuk membangun kehidupan masyarakat dan bangsa yang lebih baik.

\section{Tujuan Penilaian}

Dalam Kurikulum 2013 penilaian mengacu pada Permendikbud Nompr 66 Tahun 2013 tentang standar Pendidikan Standar Penilaian bertujuan untuk menjamin: (1) perencanaaan penilaian peserta didik sesuai dengan kompetensi yang akan dicapai berdaearkan prinsip-prinsip penilaian, (2) pelaksanaan penilaian peserta didik secara profesional, terbuka, edukatif, efektif, efisien, dan sesuai dengan konteks sosial budaya, (3) pelaporan hasil penilaian peserta didik secara objektif, akuntabel dan informatif. Standar penilaian pendidikan

${ }^{23}$ Hamalik, Manajemen pengembangan kurikulum, 98.

24 Penilaian Autentik (Penilaian Hasil Belajar Peserta Didik Berdasarkan Kurikulum 2013), Suatu Pendekatan Praktis | Perpustakaan FIS, 32. 
disusun sebagai acuan penilaian bagi pendidik,satuan pendidikan, dan pemerintah pada satuan pendidikan untuk jenjang pendidikan dasar dan menengah. ${ }^{25}$

Penilaian pendidikan sebagai proses pengumpulan dan pengolahan informasi untuk mengukur pencapaian hasil belajar peserta didik mencakup: penilaian autentik, penilaian diri, penilaian berbasis portofolio, ulangan, ulangan harian, ulangan tengah semester, ulangan akhir semester, ujian tingkat kompetensi, ujian mutu tingkat kompetensi, ujian nasional, dan ujian sekolah /madrasah. ${ }^{26}$

Tujuan penilaian dalam kurikulum berbasis kompetensi secara umum adalah untuk mengetahui apakah peserta didik telah atau belum menguasai suatu kompetensi dasar tertentu. Secara lebih spesifik tujuan penilaian adalah: 1) Untuk mengetahui tingkat pencapaian siswa. 2) Mengukur pertumbuhan dan perkembangan sisiwa. 3) Mendiagnosis kesulitan belajar siswa. 4) Untuk memperoleh masukan atau umpan balik bagi guru dan siswa dalam rangka perbaikan. $^{27}$

\section{Manfaat Penilaian Pengetahuan Tertulis}

Evaluasi (penilaian) merupakan bagian penting dalam suatu sistem instruksional karena itu penilaian mendapat tanggung jawab untuk melaksanakan fungsi-fungsi pokok sebagai berikut :

Fungsi Edukatif: : Dengan penilaian dapat diketahu tingkat kemampuan belajar siswa, sehingga dapat dinuat konsep nahan ajar yang sifatnya nilai pendidikan bagi siswa

Fungsi instusional : Penilaian merupakan hal penting dalam suatu lembaga agar dapat mengukur tingkat kemempuan perkembangan mutu pendidikan suatu lembaga khususnya sekolah/madrasah

Fungsi diagnostik: Dengan penilaian dapat diketahui kesulitan masalahmasalah yang sedang dihadapi oleh siswa dalam proses

${ }^{25}$ Kusnandar, Penilaian Autentik, 2013: 35

26 Permendikbud Nomor 66 Tahun 2013 tentang Standar Penilaian Pendidikan. 2

27 Evaluasi Hasil Belajar, Bina Mitra Pembinaan Madrasah, Depag RI MP3 A. Jakarta: LBMPM Jakarta, 2006: 5 


\section{Nurul Waizah, Herwani}

kegiatanbelajarnya. Dengan informasi tersebut maka dapat dirancang dan digunakan unuk menanggulangi dan atau membantu yang bersangkutan mengatasi kesulitannya dan atau memecahkan masalahnya.

Fungsi administratif : Evaluasi menyediakan data tentang kemajuan belajar siswa, yang pada gilirannya berguna untuk memberikan tanda kelulusan dan untuk melanjutkan studi lebih lamjut dan/atau untuk kenaikan kelas.juga untuk mengetahui tingkat kemampuan guru-guru dalam proses belajar-mengajar (PBM) yang berguna untuk kepentingan supervisi.

Fungsi kurikuler: Evaluasi berfungsi menyediakan data dan informasi yang akurat dan berdaya guna bagi pengembangan kurikulum (perencanaaan, uji coba di lapangan, implementasi dan revisi).

Fungsi manajemen : Komponen evaluasi merupakan bagian integral dalam sistem manajemen, hasil evaluasi berdayaguna sebagai bahan bagi pimpinan untuk membuat keputusan manajemen pada semua jenjang manajemen.

Menurut Abdul Rahman Saleh fungsi penilaian antara lain adalah: 1) Fungsi seleksi yaitu menyeleksi calon peserta suatu lembaga pendidikan kursus sesuai kriteria tertentu. 2) Fungsi penempatan agar setiap orang peserta pendidikan mengikuti pendidikan pada jenis dan atau jemjang pendidikan yang sesuai dengan bakat dan kemampuannya masing-masing. 3) Fungsi diagnostik yaitu untuk mengidentifikasi kesulitan belajar yang dialami peserta didik menntukan faktor-faktor yang menyebabkan terjadinya kesulitan belajar dan menetapkan cara mengatasi kesulitan belajar tersebut. ${ }^{28}$

\section{Langkah-Langkah Penilaian Pengetahuan Tertulis}

Agar dapat memperoleh tes tertulis yang berkualitas ada beberapa langkah yang harus diperhatikan dalam mengkonstruksi tes tersebut yaitu:

\section{Menetapkan tujuan tes}

Tes hasil belajar dapat dibuat untuk nermacam-macam tujuan seperti: 1) Evaluasi belajar pada akhir program (harian, semesteran, kenaikan kelas, kelulusan) 2) Seleksi, misalnya untuk ujian saringan

${ }^{28}$ MP3A, Evaluasi Hasil Belajar. 5 
masuk ke sekolah lebih lanjut. 3 Diagnosis kesuliuatn belajar yang dikenal dengan tes diagnostik.

\section{Analisis kurikulum/Analisi kompetensi}

Analisis kurikulum bertujuan untuk menentukan bobot sebagai standar kompetensi dan kompetensi dasar sebagai acuan dalam menentukan jumlah item atau butir soal baik soal objektif maupun soal bentuk uraian pada setiap materi pokok.Penentuan bobot untuk setiap kompetensi dilakukan berdasarkan jumlah jam pertemuan (alokasi waktu) yang tercantum silabus pembelajaran.

\section{Membuat kisi-kisi Soal}

Kisi-kisi adalah suatu format atau matriks yang memuat kriteria tentang soal-soal yang diperlukan oleh suatu tes atau ujian.Kisi-kisi atau Blueprint atau Table af Spesification bermanfaat untuk menjamin sampai soal yang baik dalam arti mencakup semua kompetensi secara proporsional.

\section{Penulisan Indikator}

Penulisan indikator harys sesuai dengan ketentuan yang telah ditetapkan Indikator harus mencerminkan tingkah laku peserta didik, oleh karena itu harus dirumuskan secara teknis menggunakan kata-kata operasional.

\section{Penulisan Soal}

Beberapa petunjuk yang harus diperhatikan dalam penulisan soal adalah: 1) Soal yang dibuat harus valid artinya mampu mengukur tercapai tidaknya indikator kompetensi yang dirumuskan. 2) Soal dapat dikerjakan secara spesifik. Soal yang dibuat menggunakan bahasa yang sederhana dan mufah dimengerti.tidak menimbulkan salah tafsir atau tafsiran ganda. 3) Soal yang dibuat harus terlebih dahulu dikerjakan atua diselesaikan dengan langkah-langkah lengkap sebelum dugunakan dalam tes yang sesungguhnya. 4) Hindari kesalahan ketik betapapun kecilnya karena dapat mempengaruhi validiras. 5) Menetapkan sejak awal kememuan yang harus diukur untuk setiap sola yang dibuat. 6) Berikan petunjuk mengerjakan soal secara lengkap dan jelas untuk setiap betuk soal dalam suatu tes 


\section{Nurul Waizah, Herwani}

\section{Reproduksi tes terbatas}

Tes yang sudah dibuat diperbanyak dalam dalam jumlah yang cukup menurut jumlah sampel uji-coba atau jumlah peserta yang akan mengrjakan tes tersebut dalam suatu kegiatan uji coba tes.

\section{Uji-coba Tes}

Sampel uji-coba harus mempunyai karakteristik yang kurang lebih sama dengan peserta tes yang sesungguhnya.

\section{Analisis hasil uji coba}

Berdasarkan data hasil uji coba dilakukan analisis meliputi validitas butir, tingkat kesukaran, dan fungsi pengecoh. Soal yang valid akan ditetapkan atau dirakit menjadi suatu tes yang valid untuk memberikan gambaran kualitas tes tersebut secara empirik dihitung realibitasnya.

\section{Revisi Soal}

Revisi soal dilakukan untuk soal valid yang belum memenuhi syarat berdasarkan konfirmasi dengan kisi-kisi dapat diperbaiki atau direvisi seduai keperluan

\section{Merakit soal menjadi tes}

Soal-soal yang valid telah mencerminkan semua poko bahasan serta aspek kemampuan ynag hendak diukur dapat dirakit menjadi sebuah tes yang valid. Urutan soal dalam suatu tes pada umumnya dilakukan menurut tingkat kesukaran soal dari soal yang mudah sampai soal yang sulit. 29

\section{Cara Penilaian Pengetahuan Tertulis}

Cara penilaian disebut juga dengan teknik penilaian. Teknik kompetensi pengetahuan atau kognitif adalah penilaian yang dilakukan guru untuk mengukur tingkat pencapaian atau penugasan peserta didik dalam aspek pengetahuan yang meliputi ingatan/hafalan, pemahaman, penerapan/aplikasi, analisis, sintesis dan evaluasi. Dalam Kurikulum 2013 kompetensi pengetahuan menjadi kompetensi inti (KI 3). Kompetensi pengetahuan merefleksikan konsep-konsep ilmuan yang harus dikuasai oleh peserta didik melalui proses belajar mengajar KI 3 yaitu memahami

${ }^{29}$ MP3 A Evaluasi hasl belajar. 50 
pengetahuan faktual dengan cara mengamati (mendengar, melihat, membaca) dan menanya berdasarkan rasa ingin tahu tentang dirinya, makhluk ciptaan Tuhan dan kegiatannya, dan benda-benda yang dijumpainya di rumah dan di sekolah. ${ }^{30}$

Ada beberapa cara atau teknik menilai dalam penilaian berbasis kelas yakni tes tertulis, penilaian produk, unjuk kerja, portofolio dan penilaian sikap. Jenis penilaian dalam aspek pengetahuan dapat berupa:

Tes tertulis: Tes tertulis yang digunakan guru banyak variasinya yang mana digunakan untuk mengukur pencapaian kompetensi pengetahuan (kognitif) peserta didik, tes tertulis terdiri dari soal pilihan ganda, isian, jawaban singkat (pendek), benar-salah, penjodohan dan uraian. ${ }^{31}$

Tes Lisan: Tes bentuk lisan adalah tes yang dipergunakan mengukur tingkat pencapaian kompetensi, terutama pengetahuan (kognitif) di mana guru memberikan pertanyaan langsung kepada peserta didik secara verbal (lisan) dan ditanggapi secara langsung oleh peserta didik.

Tes Penugasan/Proyek: Instrumen penugasan berbentuk pekerjaan rumah dan proyek yang dikerjakan secara individu atau kelompok sesuai dengan karakteristik tugas. ${ }^{32}$ Penilaian tes tertulis (Paper and Pencil Test) sangat efektif untuk mengukur kemampuan penguasaan materi (kognitif). Penilaian tertulis dilaksanakan untuk waktu yang terbatas dan dalam kondisi tertentu. Tes tertulis secara umum ada 2 macam, yakni tes objektif dan tes uraian (esai). Tes objektif terdiri dari pilihan ganda (multiple choiche), benar-salah (true-false), menjodohkan (matching), isian singkat (short answer), melengkapi (completion).

Berbagai bentuk tes objektif tersebut hanya mampu menilai kemampuan kognitif tingkat rendah (ingatan-pemahaman), namun untuk pilihan ganda bagi penyusun butir soal profesional dapat menilai seluruh

30 Kementerian Pendidikan dan Kebudayaan, Dokumen Kurikulum 2013, Jakarta: Kemendikbud, 2013: 5

${ }^{31}$ Trianto and Titik Triwulan Tutik, Tinjauan Yuridis Hak Serta Kewajiban Pendidik Menurut UU Guru Dan Dosen, Cet. 1 (Jakarta, Indonesia: Prestasi Pustaka Publisher, 2006).

32 Sholeh Hidayat, Pengembangan Kurikulum Baru (Bandung: Remaja Rosda Karya, 2013), 119.

Vol.2, No.2, July 2021

Tafkir: Interdisciplinary Journal of Islamic Education 


\section{Nurul Waizah, Herwani}

tingkatan kognitif dari rendah sampai tinggi. Untuk kegiatan ulangan harian yang cakupan kompetensi/materinya sedikit atau jumlah peserta didik sedikit hendaknya dihindari penggunaan tes objektif, agar peserta didik terbiasa mengorganisasikan pikiran dalam jawabannya dengan tes uraian.Tes uraian (esai) ada 2 macam yakni uraian terbatas atau terstruktur dan uraian bebas. ${ }^{33}$

\section{Contoh Penilaian Pengetahuan Tertulis}

Jika dilihat dari bentuk jawaban peserta didik, maka tes dapat dibagi menjaditiga jenis, yautu tes tertulis, tes lisan dan tes perbuatan. ${ }^{34}$ Tes tertulis ada dua bentuk yaitu bentuk objektif dan tes uraian (Essay).

Tes Hasil Belajar Bentuk Objektif: Tes objektif disebut objektif karena cara pemeriksannya terhadap semua peserta didik yang mengikuti tes. Tes objektif juga dikenal dengan istilah tes jawaban pendek (short answer test), dan salah datu tes hasil belajar yang terdiri dari butir0btir soal (items) yang dapat dijawab oleh tester. Dengan jalan memilih salah satu atau lebih, di antara beberapa kemungkinan jawaban yang telah dipasangkan pada masing-masing items atau dengan jalan menuliskan jawabannya berupa kata-kata atau simbol-simbol tertentu pada tempat-tempat yang disediakan untuk masing-masing butir yang bersangkutan. Berikut beberapa jenis tes bentuk objektif yaitu:

\section{Test objektif bentuk multifle choice test (Pilihan berganda)}

Tes multifle choice, tes pilihan gamda merupakan tes objektif dimana maisng-masing tes disediakan lebih dari kemungkinan jawaban dan hana satu dari pilihan-pilihan tersebut yang benar atau yang palung benar. Penyusunan tes dalam bentuk multifle choice hendaknya antara pernyataan dalam soal dengan alternatif jawaban terdapat kesesuaian, kalimat tiap-tiap butir soal dapat disusun dengan jelas, soal yang disusun hendaknya mudah dipahami, setiap butir pertanyaan

${ }_{33}$ MP3A, Evaluasi Hasil Belajar, 41

34 Asrul, Rusydi Ananda, Rosnita, Evaluasi Pembelajaran, Bandung: Cita Pustaka Media, 2015: 42

Vol.2, No.2, July 2021

Tafkir: Interdisciplinary Journal of Islamic Education 
hanya mengandung satu masalah, meskipun masalahnya agak kompleks.

\section{Test objektif Bentuk Benar-Salah (True-false)}

Bentuk soal benar-salah adalah bentuk tes yang soal-soalnya beriupa pernyataan.Sebagaian pernyataan itu merupakan pernyataan yang benar dan sebagian merupakan pernyataan salah. Tes ini juga dikenal bentuk "Ya-Tidak".

\section{Test Objektif bentuk Jawaban singkat (short answer)}

Bentuk soal jawaban singkat merupakan soal yang menghendaki jawaban dalam bentuk kata, bilangan, kalimat atau simbol dan jawabannya hanya dapat dinilai benar atau salah.

\section{Melengkapi (completion test)}

Item completion terdiri dari suatu statemen atau kalimat yang belum sempurna, peserta didik disuruh melengkapi statemen atau kalimat tersebut dengan satu atau beberapa perkataan pada titik-titik yang disediakan. Contoh: Penyakit...disebabkan karena kekurangan Vitamin B

\section{Menjodohkan (matching)}

Bentuk soal menjodohkan terdiri atas dua kelompok pernyataan yang paralel. Kedua kelompok pernyataaan ini berada dalam satu kesatuan. Kelompok sebelah kiri merupakan bagian yang berisi soal-soal yang harus diisi jawabannya. Ciri-ciri tes ini adalah: 1) Tes terdiri dari satu seri pertanyaan dan seri jawaban, 2) tugas tes adalah mencari dan menetapkan jawaban-jawaban yang telah tersedia sehingga sesuai dengan atau cocok dan merupakan pasangan "jodoh" dari pertanyaan.

\section{Tes Objektif bentuk Fill-in (Isian)}

Soal tes bentuk fill- in ini biasanya berbentuk cerita atau karangan. Kriteria penyusunan tes bentuk fill-in meliputi hendaknya jawaban yang harus diisikan ditulis pada lembar jawaban atau pada tempat terpisah, ungkapan cerita yang disusun seringkas mungkin 


\section{Nurul Waizah, Herwani}

untuk menghemat kertas atau tempat serta waktu penyesuaiannya, apabila jenis mata pelajaran yang akan disajikan memungkinkan pengajaran atau pengujian soal juga dapat dituangkan dalam bentuk gambar.

Tes bentuk uraian (essay test) yang terdiri dari : 1) Tes uraian bebas (free essay) atau di sebut juga dengan (extended respons items). Tes uraian ini jawaban peserta didik tidak dibatasi, bergantung pada pandangan peserta didik itu sendiri. 2) Tes uraian terbatas / terstruktur (restricted respons items) Tes bentuk ini pertanyaan telah diarahkan kepada hal-hal tertentu atau ada pembahasan tertentu. Pembatasan bisa dari segi: ruang lingkupnya. sudut pandang menjawabnya, indikator-indikatornya.

\section{Peluang Pengembangan Penilaian dalam Pembelajaran}

Kurikulum 2013 mempertegas adanya pergeseran dalam melakukan penilaian yang pada asalnya daei penilaian melalui tes yaitu mengukur kompetensi pengetahuan menuju penilaian autentik yaitu mengukur kompetensi sikap, pengetahuan, dan keterampilan berdasarkan proses dan hasil yang meminta peserta didik mampu menerapkan konsep atau teori pada dunia nyata seperti di lingkungan keluarga, tetangga, sekolah, dan masyarakat.

Saat ini kegiatan penilaian hasil belajar di madrasah meliputi 1) penilaian harian (PH), 2) penilaian akhir smester (PAS), 3) penilaian Akhir Tahun (PAT), 4) ujian madrasah (UM). Jenis-jenis tagihan di atas merupakan bagian bagian dari penilaian yang harus dilakukan guru untuk mengukur kognitif peserta didik dengan objektif. Seiring dengan perkembangan abad ke-21 ini guru atau pendidik harus memiliki karakteristik mempunyai jiwa kepemimpinan,mempunyai visi menjadi model atau teladan, mampu berkolaborasi, siap mengambil resiko, dapat beradaptasi, selalu mau meningkatkan kemampuan diri (pembelajaran sepanjang hayat), serta mampu berkomunikasi. Di samping itu guru juga harus memaham prinsip-prinsip dalam proses pembelajaran yang juga mengalami perubahan.

Pembelajaran abad ke-21 menerapkan prinsip-prinsip pembelajaran peserta didik antara lain : (1) pembelajaran dengan metode ilmiah. (2) inquiry/discovery learning (3) project based learning, dan (4) problem based learning. 
Melalui keterlibatan aktif peserta didik dalam aktivitas-aktivitas belajar pada langkah-langkah pembelajaran, metode-metode, sikap/nilai karakter, pengetahuan, keterampilan, kecakapan abad 21, kecakapan literasi dan kecakapan berpikir tingkat tinggi akan otomatis diperoleh peserta didik.

\section{KESIMPULAN}

Penilaian kompetensi pengetahuan atau kognitif adalah penilaian yang dilakukan guru untuk mengukur tingkat pencapaian atau penguasaan peserta didik dalam aspek pengetahuan yang meliputi ingatan atau hafalan, pemahaman, penerapan atau aplikasi, analisis, sintesis dan evaluasi. Kurikulum 2013 adalah sebagai landasan filosofi yang mengembangkan seluruh potensi peserta didik menjadi manusia yang berkualitas. Tujuan penilaian tertulis adalah umtuk mengetahui tingkat pencapaian, mengukur pertumbuhan dan perkembangan diri peserta didik, mendiagnosisi kesulitan belajar, untuk memperoleh masukan atau umpan balik bagi guru dan peserta didik dalam rangka perbaikan. Fungsi penilaian pengetahuan tertulis diantaranya adalah : fungsi edukatif, instusional,diagnosis, administratif. Kurikuler, manajemen, seleksi dan penempatan. Langkah-langkah penilaian pengetahuan tertulis: menetapkan tujuan tes, analisis materi/kompetensi, membuat kisi-kisi, penulisan soal, reproduksi tes, uji coba tes, analisis hasil uji coba, rincian soal, dan merakit soal tes.

Peluang pengembangan penilaian pengetahuan tertulis pada pembelajaran sudah tercantum pada Kurikilum 2013 yang mempertegas adanya pengembangan penilaian mengukur pengetahuan menjadi penilaian autentik. Pada abad ke -21 ini menuntut adanya perubahan seperti bentuk soal tertulis dari keterampilan berpikir tingkat rendah yaitu mengingat dan memahami atau LOTS menjadi HOTS. Demikian pula bagi pendidik harus memahami prinsip-prinsip pembelajaran maupun model-model pembelajaran. Sebagai contoh adanya penilaian formatif digunakan tidak hanya penilaian untuk pembelajaran (assesment for learning) tapi juga penilaian sebagai pembelajaran (assesment as learning). 


\section{REFERENSI}

Amri, Loeloek Endah Poerwati ; Sofan. Panduan Memahami Kurikulum 2013 : Sebuah Inovasi Struktur Kurikulum Penunjang Masa Depan. Jakarta: Prestasi Pustaka Pub, 2013.

Andres, Hayward P. 'Active Teaching to Manage Course Difficulty and Learning Motivation'. Journal of Further and Higher Education 43, no. 2 (7 February 2019): 220-35. https://doi.org/10.1080/0309877X.2017.1357073.

Arifin, Zainal. 'Evaluasi Pembelajaran'. Bandung: Remaja Rosdakarya 77 (2009). http://dualmode.kemenag.go.id/file/ dokumen/34EvaluasiPembelajaran.pdf.

Ashaari, Muhamad Faisal, Zainab Ismail, Anuar Puteh, Mohd Adib Samsudin, Munawar Ismail, Razaleigh Kawangit, Hakim Zainal, Badlihisham Mohd Nasir, and Mohd Ismath Ramzi. 'An Assessment of Teaching and Learning Methodology in Islamic Studies'. Procedia - Social and Behavioral Sciences, Universiti Kebangsaan Malaysia Teaching and Learning Congress 2011, Volume I, December 17 - 20 2011, Pulau Pinang MALAYSIA, 59 (17 October 2012): 618-26. https:// doi.org/10.1016/j.sbspro.2012.09.322.

Asyari, Saiful. 'Supervisi Kepala Madrasah Berbasis Penilaian Kinerja Sebagai Upaya Peningkatan Profesionalitas Guru'. JIEMAN: Journal of Islamic Educational Management 1, no. 2 (24 June 2020): 149-63. https://doi.org/10.35719/jieman.v1i2.14.

Atikah, Atikah, Nasir Widha Setyanto, and Ceria Farela Mada Tantrika. 'Perancangan Penilaian Kinerja Guru Berdasarkan Standar Kualifikasi Akademik Kompetensi Guru Dan Kompetensi Gomes Sebagai Acuan Pemberian Insentif (Studi Kasus Sma Brawijaya Smart School, Malang)'. Jurnal Rekayasa Dan Manajemen Sistem $\begin{array}{lllll}\text { Industri } & 1 & \text { no. } & 3 & \text { (2013): }\end{array}$ http://jrmsi.studentjournal.ub.ac.id/index.php/jrmsi/article/view/53.

Bahrissalim, Bahrissalim, and Fauzan Fauzan. 'Evaluasi Kurikulum Pelatihan Dalam Meningkatkan Kompetensi Pedagogik Guru Pai Di Balai Diklat Keagamaan Jakarta'. Edukasia: Jurnal Penelitian Pendidikan Islam 13, no. 1 (25 July 2018): 2552. https:// doi.org/10.21043/edukasia.v13i1.2779. 
Brodhead, Matthew T., Emily A. Abel, Monerah N. Al-Dubayan, Lauren Brouwers, Gina Warren Abston, and Mandy J. Rispoli. 'An Evaluation of a Brief MultipleStimulus Without Replacement Preference Assessment Conducted in an Electronic Pictorial Format'. Journal of Behavioral Education 25, no. 4 (1 December 2016): 417-30. https://doi.org/10.1007/s10864-016-9254-3.

Drugan, Joanna. Quality In Professional Translation: Assessment and Improvement. A\&amp;C Black, 2013.

Dunmade, Israel. 'Lifecycle Assessment Education in Nigeria: An Exploratory Evaluation of the Trend'. Procedia Manufacturing 35 (1 January 2019): 447-52. https://doi.org/10.1016/j.promfg.2019.05.065.

Fuad, Ah Zakki. 'Rekonstruksi Tujuan Pendidikan Islam Berbasis Taksonomi Transenden'. ISLAMICA: Jurnal Studi Keislaman 9, no. 2 (15 March 2016): 424-46. https://doi.org/10.15642/islamica.2015.9.2.424-446.

Hamalik, Oemar. Manajemen pengembangan kurikulum. Sekolah Pascasarjana Universitas Pendidikan Indonesia dengan PT Remaja Rosdakarya, 2006.

- - - Proses belajar mengajar. Bumi Aksara, 2004.

Hidayat, Sholeh. Pengembangan Kurikulum Baru. Bandung: Remaja Rosda Karya, 2013. Ilmi, Munaya Ulil, Farid Setiawan, Maulida Nurul Hikmah, Arrum Kharisma, Dimas Feryawan, and Aiman Affan Hanafie. 'The Basic Concepts of Evaluation and Its Implementation in IRE Lessons in The Pandemic Era'. Tafkir: Interdisciplinary Journal of Islamic Education 2, no. 2 (30 July 2021): 175-90. https://doi.org/10.31538/tijie.v2i2.50.

Indratno, A. Ferry; Forum Mangunwijaya VII : Menyambut Kurikulum 2013. Jakarta: PT Kompas Media Nusantara, 2013. / / library.alizhar.sch.id/slims8_akasia/index.php?p=show_detail\&id=2321.

Jeprianto, Jeprianto, Ubabuddin Ubabuddin, and Herwani Herwani. 'Penilaian Pengetahuan Penugasan Dalam Pembelajaran Di Sekolah'. Munaddhomah: Jurnal Manajemen Pendidikan Islam 2, no. 1 (23 June 2021): 16-20. https:// pasca.jurnalikhac.ac.id/index.php/munaddhomah/article/view/55.

Kunandar. Penilaian Autentik (Penilaian Hasil Belajar Peserta Didik Berdasarkan Kurikulum 2013), Suatu Pendekatan Praktis I Perpustakaan FIS. Jakarta: Raja Grafindo 


\section{Nurul Waizah, Herwani}

Persada,

2013.

//library.fis.uny.ac.id\%2Fopac\%2Findex.php\%3Fp\%3Dshow_detail\%26id\%3D 6258.

Mahfud, Choirul. 'Evaluation of Islamic Education Curriculum Policy in Indonesia'. Premiere Educandum: Jurnal Pendidikan Dasar Dan Pembelajaran 9, no. 1 (2019): 3443.

Mulyasa, E. Pengembangan Dan Implementasi Kurikulum 2013. Cetakan pertama. Bandung: PT Remaja Rosdakarya, 2013.

Muzamirah, Latifatul Mida. Kupas Tuntas Kurikulum 2013: Kelebihan Dan Kekurangan Kurikulum 2013 | Perpustakaan Universitas Negeri Jakarta. Yogjakarta: Kata Pena, 2013.

//lib.unj.ac.id\%2Fbuku\%2Findex.php\%3Fp\%3Dshow_detail\%26id\%3D34149\% 26keywords\%3D.

PERCIVAL, N. J., P. J. SYKES, and T. CHANDRAPRAKASAM. 'A Method of Assessment of Pollicisation'. Journal of Hand Surgery 16, no. 2 (1 April 1991): 141-43. https://doi.org/10.1016/0266-7681(91)90163-I.

Suryanto, Adi. 'Evaluasi Pembelajaran Di SD', 1:1-49. Jakarta: Universitas Terbuka, 2014. http:// repository.ut.ac.id/4070/.

Suyanto. Refleksi Dan Reformasi Pendidikan Di Indonesia Memasuki Milenium III. Yogjakarta: Adicita Karya Nusa, 2000.

Trianto, and Titik Triwulan Tutik. Tinjauan Yuridis Hak Serta Kewajiban Pendidik Menurut UU Guru Dan Dosen. Cet. 1. Jakarta, Indonesia: Prestasi Pustaka Publisher, 2006.

Veerman, Gert-Jan M., Herman G. van de Werfhorst, and Jaap Dronkers. 'Ethnic Composition of the Class and Educational Performance in Primary Education in The Netherlands'. Educational Research and Evaluation 19, no. 5 (1 July 2013): 370-401. https:// doi.org/10.1080/13803611.2013.788851.

Vol.2, No.2, July 2021

Tafkir: Interdisciplinary Journal of Islamic Education 